\title{
Detection of the outer membrane lipoprotein I and its gene in fluorescent and non-fluorescent pseudomonads: implications for taxonomy and diagnosis
}

\author{
D. De Vos, ${ }^{1}$ A. Lim, JR, ${ }^{1}$ P. De Vos, ${ }^{2}$ A. Sarniguet, ${ }^{3}$ K. Kersters ${ }^{2}$ and P. Cornelis ${ }^{1 *}$ \\ ${ }^{1}$ Laboratorium Algemene Biologie, Vrije Universiteit Brussel, Paardenstraat 65, B-1640 St-Genesius Rode, Belgium \\ ${ }^{2}$ Laboratorium voor Microbiologie, Universiteit Gent, K.L. Ledeganckstraat 35, B-9000 Gent, Belgium \\ ${ }^{3}$ INRA, Centre de Recherche de Rennes, Station de Pathologie Végétale, B.P. 26, 35650 Le Rheu, France
}

(Received 11 November 1992; revised 31 March 1993; accepted 2 April 1993)

\begin{abstract}
The open reading frame of the OprI lipoprotein gene from Pseudomonas aeruginosa was amplified by polymerase chain reaction (PCR) starting from purified DNA or colony lysates. A fragment of the expected size (249 bp) was detected in all $P$. aeruginosa strains from various clinical and geographical origins. The gene could only be amplified in pseudomonads of rRNA group I which are considered to be the authentic genus Pseudomonas. Digestions with $\mathrm{HaeIII}, P v u I I$ and $S p h I$ of the amplified fragments demonstrated a sequence variation in the oprI gene. Colony, dot and Western blots with two monoclonal antibodies (mAbs) against the lipoprotein I confirmed our PCR results. These findings open interesting perspectives for the molecular taxonomy of the genus Pseudomonas and the development of diagnostic tools.
\end{abstract}

\section{Introduction}

Pseudomonas aeruginosa is a typical opportunistic pathogen (Botzenhart \& Rüden, 1987). It is more and more frequently recognized as a causative agent of a variety of mostly complicated and often fatal infections (Bodey et al., 1983; Mondino et al., 1986), including septicaemia (Bodey et al., 1985) and lung infections in patients with cystic fibrosis (Govan, 1986; Hoiby et al., 1987). In view of the increasing clinical importance of $P$. aeruginosa, the development of a rapid and specific diagnostic test based on the polymerase chain reaction (PCR) and/or monoclonal antibody $(\mathrm{mAb})$ detection could contribute to a better management of this clinical pathogen. According to Saint-Onge et al. (1992) the oprI gene is a generally applicable PCR target region for the Pseudomonas species of rRNA group I (Palleroni, 1984), which is at present considered to be the authentic genus Pseudomonas (De Vos \& De Ley, 1983). However, in addition to the rRNA group I Pseudomonas species (Palleroni, 1984) which were partly included by Saint-Onge et al. (1992), many more phytopathogenic and saprophytic species which have the name Pseudomonas belong to this phylogenetic group (De Vos et al., 1985, 1989). Therefore

\footnotetext{
*Author for correspondence. Tel. 2 3590258; fax 23590390.

Abbreviations: mAb, monoclonal antibody; RFLP, restriction fragment length polymorphism.
}

we extended the experiments of Saint-Onge et al. (1992) by including other Pseudomonas rRNA group I members as well as the free-living nitrogen-fixing Azotobacter and Azomonas species which are also located in the same phylogenetic neighbourhood as the authentic pseudomonads (De Vos \& De Ley, 1983).

The question then arises whether the oprI amplification can be used for a specific detection of Pseudomonas aeruginosa strains or of other important fluorescent pseudomonads acting as plant-growth-promoting rhizobacteria (Davison, 1988; Weller, 1988). We compared the PvuII, HaeIII and SphI restriction patterns of the amplificates of the different organisms in order to find a species-specific profile for $P$. aeruginosa and closelyrelated organisms. This knowledge will not only enhance the development of a specific diagnostic test but will also provide complementary genotypic data for the classification of the Pseudomonas species from rRNA group I at species and subspecies level. At present, the finer classification of this important group of micro-organisms is not well defined and identifications are often not reliable.

\section{Methods}

Bacterial strains and growth conditions. The bacterial strains used are listed in Table 1. Strains not obtained from culture collections were identified according to classical bacteriological procedures. The bacteria were grown overnight in $3 \mathrm{ml}$ Luria-Bertani (LB) broth 
Table 1. Bacterial species used in this study

The Pseudomonas species outside rRNA group I (Palleroni, 1984) are misclassified and the genus name is therefore mentioned in brackets.

\begin{tabular}{|c|c|c|c|c|}
\hline Species & Strain* & $\begin{array}{l}\text { Geographical } \\
\text { origin }\end{array}$ & Source & Provided by $\dagger$ \\
\hline Pseudomonas aeruginosa & PAO 1 & France & Clinical isolate, wild type & J. M. Meyer, ULP, Strasbourg \\
\hline$P$. aeruginosa & PA 3 & Belgium & Clinical isolate, cystic fibrosis & G. Wauters, UCL, Brussels \\
\hline P. aeruginosa & PA 4 & Belgium & Clinical isolate, urinary infection & G. Wauters, UCL, Brussels \\
\hline$P$. aeruginosa & PA 5 & Belgium & Clinical isolate, urinary infection & G. Wauters, UCL, Brussels \\
\hline$P$. aeruginosa & PA 6 & Belgium & Clinical isolate, Intensive Care unit & G. Wauters, UCL, Brussels \\
\hline P. aeruginosa & PA 7 & Belgium & Clinical isolate, urinary infection & G. Wauters, UCL, Brussels \\
\hline P. aeruginosa & PA 8 & Belgium & Clinical isolate, urinary infection & G. Wauters, UCL, Brussels \\
\hline P. aeruginosa & PA 10 & Belgium & Clinical isolate, urinary infection & G. Wauters, UCL, Brussels \\
\hline P. aeruginosa & PA 11 & Belgium & Clinical isolate, urinary infection & G. Wauters, UCL, Brussels \\
\hline$P$. aeruginosa & PA 12 & Belgium & Clinical isolate, urinary infection & G. Wauters, UCL, Brussels \\
\hline P. aeruginosa & PA 1022 & Belgium & Clinical isolate & $\begin{array}{l}\text { H. Goossens, U.Z. Sint Pieters, } \\
\text { Brussels }\end{array}$ \\
\hline P. aeruginosa & PA 1601 & Belgium & Clinical isolate & $\begin{array}{l}\text { H. Goossens, U.Z. Sint Pieters, } \\
\text { Brussels }\end{array}$ \\
\hline$P$. aeruginosa & PA 2001 & Belgium & Clinical isolate & $\begin{array}{l}\text { H. Goossens, U.Z. Sint Pieters, } \\
\text { Brussels }\end{array}$ \\
\hline P. aeruginosa & PA 2019 & Belgium & Clinical isolate & $\begin{array}{l}\text { H. Goossens, U.Z. Sint Pieters, } \\
\text { Brussels }\end{array}$ \\
\hline$P$. aeruginosa & MH 1 & Belgium & Clinical isolate, burn wound & $\begin{array}{l}\text { M. Vanderkelen, Mil. Hosp., } \\
\text { Brussels }\end{array}$ \\
\hline P. aeruginosa & MH 2 & Belgium & Clinical isolate, burn wound & $\begin{array}{l}\text { M. Vanderkelen, Mil. Hosp., } \\
\text { Brussels }\end{array}$ \\
\hline P. aeruginosa & MH 3 & Belgium & Clinical isolate, burn wound & $\begin{array}{l}\text { M. Vanderkelen, Mil. Hosp., } \\
\text { Brussels }\end{array}$ \\
\hline$P$. aeruginosa & $\mathrm{MH} 4$ & Belgium & Clinical isolate, burn wound & $\begin{array}{l}\text { M. Vanderkelen, Mil. Hosp., } \\
\text { Brussels }\end{array}$ \\
\hline$P$. aeruginosa & MH 6 & Belgium & Clinical isolate, burn wound & $\begin{array}{l}\text { M. Vanderkelen, Mil. Hosp., } \\
\text { Brussels }\end{array}$ \\
\hline P. aeruginosa & MH 7 & Belgium & Clinical isolate, burn wound & $\begin{array}{l}\text { M. Vanderkelen, Mil. Hosp., } \\
\text { Brussels }\end{array}$ \\
\hline P. aeruginosa & MH 8 & Belgium & Clinical isolate, burn wound & $\begin{array}{l}\text { M. Vanderkelen, Mil. Hosp., } \\
\text { Brussels }\end{array}$ \\
\hline P. aeruginosa & MH 9 & Belgium & Clinical isolate, burn wound & $\begin{array}{l}\text { M. Vanderkelen, Mil. Hosp., } \\
\text { Brussels }\end{array}$ \\
\hline$P$. aeruginosa & MH 10 & Belgium & Clinical isolate, burn wound & $\begin{array}{l}\text { M. Vanderkelen, Mil. Hosp., } \\
\text { Brussels }\end{array}$ \\
\hline$P$. aeruginosa & DW 1 & Philippines & Clinical isolate, urinary infection & $\begin{array}{l}\text { F. de la Peña, R. de los Reyes, } \\
\text { DWU, Tacloban }\end{array}$ \\
\hline P. aeruginosa & DW 2 & Philippines & Clinical isolate, bacteraemia & $\begin{array}{l}\text { F. de la Peña, R. de los Reyes, } \\
\text { DWU, Tacloban }\end{array}$ \\
\hline$P$. aeruginosa & DW 3 & Philippines & Clinical isolate, wound infection & $\begin{array}{l}\text { F. de la Peña, R. de los Reyes, } \\
\text { DWU, Tacloban }\end{array}$ \\
\hline P. aeruginosa & DW 4 & Philippines & Clinical isolate, wound infection & $\begin{array}{l}\text { F. de la Peña, R. de los Reyes, } \\
\text { DWU, Tacloban }\end{array}$ \\
\hline$P$, aeruginosa & DW 5 & Philippines & Clinical isolate, urinary infection & $\begin{array}{l}\text { F. de la Peña, R. de los Reyes, } \\
\text { DWU, Tacloban }\end{array}$ \\
\hline$P$. aeruginosa & DW 6 & Philippines & Clinical isolate, post operative infection & $\begin{array}{l}\text { F. de la Peña, R. de los Reyes, } \\
\text { DWU, Tacloban }\end{array}$ \\
\hline$P$. aeruginosa & PS 3707 & Australia & Clinical isolate, cystic fibrosis & B. Holloway, Monash University \\
\hline$P$. aeruginosa & PS 3880 & Australia & Clinical isolate, cystic fibrosis & B. Holloway, Monash University \\
\hline P. aeruginosa & PS 3879 & Australia & Clinical isolate, cystic fibrosis & B. Holloway, Monash University \\
\hline P. aeruginosa & PS 3883 & Australia & Clinical isolate, cystic fibrosis & B. Holloway, Monash University \\
\hline$P$. aeruginosa & PS 3711 & Australia & Clinical isolate, cystic fibrosis & B. Holloway, Monash University \\
\hline$P$. aeruginosa & 7NSK 2 & Belgium & Soil isolate & M. Höfte, RUG, Ghent \\
\hline P. agarici & LMG 2113 & New Zealand & Cultivated mushroom isolate & LMG \\
\hline P. agarici & LMG $2112^{\mathrm{T}}$ & New Zealand & Cultivated mushroom isolate & LMG \\
\hline P. agarici & LMG 2110 & United Kingdom & Cultivated mushroom isolate & LMG \\
\hline P. alcaligenes & LMG $1224^{\mathrm{T}}$ & USA & Water isolate, swimming pool & LMG \\
\hline P. asplenii & LMG $2137^{\top}$ & ND & Plant isolate, Asplenium nidus & LMG \\
\hline P. aureofaciens & LMG $1245^{\mathrm{T}}$ & The Netherlands & River clay, suspended in kerosene & LMG \\
\hline P. chlororaphis & T 9 & Belgium & $\begin{array}{l}\text { Rhizosphere isolate, Lycopersicon } \\
\text { lycopersicum }\end{array}$ & P. Thonart, ULg, Liege \\
\hline P. cichorii & LMG $2162^{\top}$ & Germany & Plant isolate, Cichorii endiva & LMG \\
\hline P. corrugata & $\mathrm{LMG} 2172^{\mathrm{T}}$ & United Kingdom & Plant isolate, Lycopersicon lycopersicum & LMG \\
\hline P. fuorescens & ATCC 17400 & USA & Poultry industry, hen's egg & J. M. Meyer, ULP, Strasbourg \\
\hline P. fluorescens & AS 1 & France & Wheat rhizosphere isolate & A. Sarniguet, INRA, Rennes \\
\hline P. fluorescens & AS 11 & France & Wheat rhizosphere isolate & A. Sarniguet, INRA, Rennes \\
\hline
\end{tabular}


Table 1. (cont.)

\begin{tabular}{|c|c|c|c|c|}
\hline Species & Strain* & $\begin{array}{l}\text { Geographical } \\
\text { origin }\end{array}$ & Source & Provided by $\dagger$ \\
\hline P. finorescens & AS 14 & France & Wheat rhizosphere isolate & A. Sarniguet, INRA, Rennes \\
\hline P. fluorescens & AS 21 & France & Wheat rhizosphere isolate & A. Sarniguet, INRA, Remnes \\
\hline P. fuorescens & AS 22 & France & Wheat rhizosphere isolate & A. Sarniguet, INRA, Rennes \\
\hline P. Aluorescens & AS 25 & France & Wheat rhizosphere isolate & A. Sarniguet, INRA, Rennes \\
\hline P. fluorescens & AS 30 & France & Wheat rhizosphere isolate & A. Sarniguet, INRA, Rennes \\
\hline P. fluorescens & AS 35 & France & Wheat rhizosphere isolate & A. Sarniguet, INRA, Rennes \\
\hline P. fluorescens & AS 37 & France & Wheat rhizosphere isolate & A. Sarniguet, INRA, Rennes \\
\hline P. fluorescens & AS 39 & France & Wheat rhizosphere isolate & A. Sarniguet, INRA, Rennes \\
\hline P. fluorescens & AS 46 & France & Wheat rhizosphere isolate & A. Sarniguet, INRA, Rennes \\
\hline P. fluorescens & AS 48 & France & Wheat rhizosphere isolate & A. Sarniguet, INRA, Rennes \\
\hline P. fragi & LMG $2191^{\mathrm{T}}$ & ND & ND & LMG \\
\hline P. fuscovaginae & LMG $2158^{\mathrm{T}}$ & Japan & Plant isolate, Oryza sativa & LMG \\
\hline P. marginalis & LMG 2238 & USA & Plant isolate, Medicago sativa & LMG \\
\hline P. marginalis & LMG 2214 & USA & & LMG \\
\hline P. mendocina & LMG $1223^{\mathrm{T}}$ & Argentina & Soil isolate, soil enrichment & LMG \\
\hline P. oleovorans & LMG $2229^{\mathrm{T}}$ & USA & Oil/water suspension & LMG \\
\hline P. pseudoalcaligenes & LMG $1225^{\mathrm{T}}$ & USA & Clinical isolate, sinus discharge & LMG \\
\hline P. putida biovar $\mathrm{A}$ & LMG $2257^{\mathrm{T}}$ & USA & Soil isolate, lactate enrichment & LMG \\
\hline P. putida biovar $\mathrm{B}$ & LMG 1246 & $\mathrm{ND}$ & ND & LMG \\
\hline P. reptilovora & LMG $2273^{\mathrm{T}}$ & $\mathrm{ND}$ & ND & LMG \\
\hline P. stutzeri & LMG $2333^{\mathrm{T}}$ & USA & Clinical isolate, spinal fluid & LMG \\
\hline P. syringae & LMG 1247 & UK & Plant isolate, Syringa vulgaris & LMG \\
\hline P. taetrolens & LMG $2336^{\mathrm{T}}$ & ND & ND & LMG \\
\hline P. tolaasii & LMG 2340 & UK & Cultivated mushroom isolate & LMG \\
\hline P. tolaasii & LMG $2342^{\Upsilon}$ & UK & Cultivated mushroom isolate & LMG \\
\hline (P.) andropogonis & LMG $2129^{\mathrm{T}}$ & USA & Plant isolate, Sorghum bicolor & LMG \\
\hline (P.) cepacia & LMG 6981 & ND & Clinical isolate, bronchial washing & LMG \\
\hline (P.) diminuta & LMG $1793^{\Upsilon}$ & USA & Water isolate, fresh water river & LMG \\
\hline (P.) gladioli & LMG 2216 & USA & Plant isolate, Gladiolus sp. & LMG \\
\hline (P.) glumae & LMG $2196^{\mathrm{T}}$ & Japan & Plant isolate, Oryza sativa & LMG \\
\hline (P.) huttiensis & LMG $2199^{\top}$ & New Zealand & Isolate from distilled water & LMG \\
\hline (P.) picketiii & LMG 6866 & ND & $\mathrm{ND}$ & LMG \\
\hline (P.) pickettii & LMG 7056 & Belgium & Clinical isolate & LMG \\
\hline (P.) pickettii & LMG $5942^{\mathrm{T}}$ & USA & Clinical isolate & LMG \\
\hline (P.) pickettii & LMG 6871 & Senegal & Rice rhizosphere isolate & LMG \\
\hline (P.) solanacearum & LMG $2299^{\mathrm{T}}$ & USA & Plant isolate, Lycopersicon lycopersicum & LMG \\
\hline (P.) solanacearum & LMG 2296 & Zimbabwe & Plant isolate, Lycopersicon lycopersicum & LMG \\
\hline (P.) solanacearum & LMG 2297 & Mauritius Islands & Plant isolate, Casuarina equisetifolia & LMG \\
\hline (P.) solanacearum & LMG 2306 & Portugal & Plant isolate, Lycopersicon lycopersicum & LMG \\
\hline (P.) vesicularis & LMG $2350^{\mathrm{T}}$ & Belgium & Leech & LMG \\
\hline (P.) woodsii & LMG $2362^{\mathrm{T}}$ & USA & Plant isolate, Dianthus caryophyllus & LMG \\
\hline Acinetobacter sp. & $\mathrm{GC} 2$ & Belgium & Clinical isolate & G. Cornelis, UCL, Brussels \\
\hline Alcaligenes eutrophus & $\mathrm{CH} 34$ & Belgium & Soil isolate & M. Mergeay, SCK-VITO, Mol \\
\hline Azomonas macrocytogenes & LMG $8755^{\mathrm{T}}$ & Denmark & Soil isolate & LMG \\
\hline Azomonas macrocytogenes & LMG 1266 & Denmark & Soil isolate & LMG \\
\hline Azotobacter paspali & LMG $3864^{\mathrm{T}}$ & Brazil & Soil isolate & LMG \\
\hline Azotobacter vinelandii & LMG 3884 & CIS, Ukraine Republik & Water isolate, Black Sea & LMG \\
\hline Chryseomonas luteola & LMG $7041^{\mathrm{T}}$ & ND & Clinical isolate & LMG \\
\hline Comamonas acidovorans & LMG $1226^{\mathrm{T}}$ & The Netherlands & Soil enrichment isolate, acetamide & LMG \\
\hline Escherichia coli & MM 294 & Belgium & Lab strain & P. Cornelis, VUB, Brussels \\
\hline Klebsiella oxytoca & $\mathrm{GC} 3$ & Belgium & Clinical isolate & G. Cornelis, UCL, Brussels \\
\hline Levinea sp. & GC 1 & Belgium & Clinical isolate & G. Cornelis, UCL, Brussels \\
\hline Proteus vulgaris & GC 5 & Belgium & Clinical isolate & G. Cornelis, UCL, Brussels \\
\hline Providencia stuartii & GC 6 & Belgium & Clinical isolate & G. Cornelis, UCL, Brussels \\
\hline Salmonella typhimurium & GC 4 & Belgium & Clinical isolate & G. Cornelis, UCL, Brussels \\
\hline Serratia marcescens & GC 7 & Belgium & Clinical isolate & G. Cornelis, UCL, Brussels \\
\hline Sphingomonas paucimobilis & LMG $1227^{\mathrm{T}}$ & United Kingdom & Hospital respirator & LMG \\
\hline Xanthomonas campestris & LMG $568^{\mathrm{T}}$ & United Kingdom & Plant isolate, Brassica sp. & LMG \\
\hline Xanthomonas maltophilia & LMG $958^{\mathrm{T}}$ & Belgium & Clinical isolate & LMG \\
\hline Xanthomonas maltophilia & HSP 1 & Belgium & Clinical isolate & $\begin{array}{l}\text { H. Goossens, U.Z. St Pieters, } \\
\text { Brussels }\end{array}$ \\
\hline Xanthomonas maltophilia & HSP 34 & Belgium & Clinical isolate & $\begin{array}{l}\text { H. Goossens, U.Z. St Pieters, } \\
\text { Brussels }\end{array}$ \\
\hline
\end{tabular}

ND, Not determined.

* T, Type strain.

+ LMG, culture collection, Laboratorium voor Microbiologie, University of Ghent, Ghent Belgium; ATCC, American Type Culture Collection, Rockville, Md, USA. 
Table 2. Results for PCR and dot blot tests with $m A b 3 A 9$ for the presence of lipoprotein I in Pseudomonas spp. and other Gram-negative organisms

\begin{tabular}{|c|c|c|c|}
\hline \multicolumn{2}{|c|}{ Species positive in PCR and dot blot } & \multicolumn{2}{|c|}{ Species negative in PCR and dot blot } \\
\hline Species & $\begin{array}{l}\text { Number } \\
\text { tested }\end{array}$ & Species & $\begin{array}{c}\text { Number } \\
\text { tested }\end{array}$ \\
\hline Pseudomonas aeruginosa & 35 & (P.) andropogonis & 1 \\
\hline P. agarici & 3 & (P.) cepacia & 1 \\
\hline P. alcaligenes & 1 & (P.) diminuta & 1 \\
\hline P. asplenii & 1 & (P.) gladioli & 1 \\
\hline$P$. aureofaciens & 1 & (P.) glumae & 1 \\
\hline P. chlororaphis & 1 & (P.) huttiensis & 1 \\
\hline P. cichorii & 1 & (P.) pickettii & 4 \\
\hline P. corrugata & 1 & (P.) solanacearum & 4 \\
\hline P. fluorescens & 13 & (P.) vesicularis & 1 \\
\hline P. fragi & 1 & (P.) woodsii & 1 \\
\hline P. fuscovaginae & 1 & Acinetobacter sp. & 1 \\
\hline$P$. marginalis & 2 & Alcaligenes eutrophus & 1 \\
\hline P. mendocina & 1 & Azomonas macrocytogenes & 2 \\
\hline P. oleovorans & 1 & Azotobacter paspali & 1 \\
\hline P. pseudoalcaligenes & 1 & Azotobacter vinelandii & 1 \\
\hline P. putida & 2 & Chryseomonas luteola & 1 \\
\hline P. reptilovora & 1 & Comamonas acidotorans & 1 \\
\hline P. stutzeri & 1 & Escherichia coli & 1 \\
\hline P. syringae & 1 & Klebsiella oxytoca & 1 \\
\hline P. taetrolens & 1 & Levinea sp. & 1 \\
\hline P. tolaasii & 2 & Proteus vulgaris & 1 \\
\hline & & Providencia stuartii & 1 \\
\hline & & Salmonella typhimurium & 1 \\
\hline & & Serratia marcescens & 1 \\
\hline & & Sphingomonas paucimobilis & 1 \\
\hline & & Xanthomonas campestris & 1 \\
\hline & & Xanthomonas maltophilia & 3 \\
\hline
\end{tabular}

medium with constant shaking at the growth temperature recommended for each species in the culture collection catalogue of the Laboratorium voor Microbiologie, Gent (LMG). Stock cultures were kept in glycerol $(50 \% \mathrm{v} / \mathrm{v})$ at $-20^{\circ} \mathrm{C}$ and in saline at $4{ }^{\circ} \mathrm{C}$.

As positive and negative controls for the expression of the lipoprotein we used E. coli JE5513 (pLPI2) (lpp ${ }^{-}$) and JE5513 (pKT240) (Cornelis et al., 1989).

DNA preparation. Unless specifically stated, all techniques involving DNA manipulations were according to Sambrook et al. (1989). Overnight cultures were centrifuged at 12000 r.p.m. for $3 \mathrm{~min}$ in a microfuge and the bacterial pellet resuspended in $450 \mu \mathrm{l}$ lysis buffer

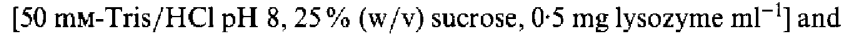
kept on ice. After $30 \mathrm{~min}, 35 \mu \mathrm{l} 0.5 \mathrm{M}$-EDTA and $45 \mu 110 \%$ (w/v) SDS were added and the tube incubated at $65^{\circ} \mathrm{C}$ for $15 \mathrm{~min}$. This was followed by a first incubation at $37^{\circ} \mathrm{C}$ for $30 \mathrm{~min}$ with $37.5 \mu \mathrm{l} 1 \mathrm{mg}$ boiled RNAase $\mathrm{A} \mathrm{ml}^{-1}$ (Sambrook et al., 1989) followed by a second incubation for $1 \mathrm{~h}$ after addition of $50 \mu \mathrm{l} 1 \mathrm{mg}$ proteinase $\mathrm{K} \mathrm{ml}^{-1}$. The DNA was finally extracted by successive treatments with phenol, phenol/chloroform and chloroform before precipitation with $3 \mathrm{M}$ sodium acetate and 2-propanol. The DNA was stored at $-20^{\circ} \mathrm{C}$ in $10 \mathrm{~mm}$-Tris/HCl, 1 mM-EDTA (TE) buffer. Dilutions $(1: 100-1: 1000)$ were used for the PCR reactions. When colony lysates were used, a single colony was resuspended in $50 \mu \mathrm{H}_{2} \mathrm{O}$ and incubated in a boiling water bath for $10 \mathrm{~min} ; 10 \mu \mathrm{l}$ of a $1: 100$ or a $1: 1000$ dilution were taken for the PCR reaction.

$P C R$ reaction. The $\mathrm{PCR}$ reaction was completed in microfuge tubes on a New Brunswick TC-1 thermocycler. The PCR mix $(100 \mu$ final volume) contained $49 \mu \mathrm{l}$ sterile distilled water, $10 \mu 110 \times$ PCR buffer (500 mm-KCl, 100 mm-Tris $/ \mathrm{HCl} \mathrm{pH} \mathrm{8.4,} 15 \mathrm{~mm}-\mathrm{MgCl}_{2}$ ), $10 \mu \mathrm{l}$ deoxy- nucleotide mix [dGTP, dTTP, dATP, dCTP (2 mM each)], $10 \mu$ diluted template DNA, $10 \mu \mathrm{l}$ of each primer $(50 \mathrm{pmol})$ and $1 \mu \mathrm{l}$ enzyme (Taq from Pharmacia or Boehringer Mannheim, Tub from Amersham). The reaction mixture was layered with $70 \mu$ l mineral oil (Sigma) to avoid evaporation. The two primers (PS1, corresponding to the beginning of the open reading frame and PS2 corresponding to the end of the open reading frame), synthesized by phosphoramidite chemistry on an ABI 391EP DNA synthesizer (Applied Biosystems) were a 27- and a 21-mer, respectively. They had the following sequences: 5'ATGAACAACGTTCTGAAATTCTCTGCT 3', for PS1; 5'CTTGCG GCT GGCTTT TTCCAG 3', for PS2. Before adding the DNA polymerase ( $2 \mathrm{U}$ per $100 \mu \mathrm{l}$ of reaction mixture), each sample was denatured at $94{ }^{\circ} \mathrm{C}$ for $5 \mathrm{~min}$. We repeated the following amplification programme for $25-30$ cycles: denaturation at $94^{\circ} \mathrm{C}$ for $1 \mathrm{~min}$, annealing at $60^{\circ} \mathrm{C}$ or $64^{\circ} \mathrm{C}$ for $1 \mathrm{~min}$, elongation at $72^{\circ} \mathrm{C}$ for $2 \mathrm{~min}$. Ten $\mu 1$ from the amplified fragment were loaded on a $1.5 \%(\mathrm{w} / \mathrm{v})$ agarose gel for electrophoresis. All PCR experiments included a positive control with $P$. aeruginosa PAO1 DNA and a negative control without DNA.

Restriction digestions. The digestion reactions were performed with $10 \mu \mathrm{l}$ crude PCR amplified fragment in a total volume of $20 \mu \mathrm{l}$ in sterile microfuge tubes containing $2 \mu 110 \times$ concentrated manufacturer's restriction buffer. The digestion mixture was incubated for $2 \mathrm{~h}$ at $37^{\circ} \mathrm{C}$, 2 units of each restriction enzyme (Boehringer-Mannheim or Pharmacia-LKB) were added to each tube. Visualization of the restriction fragments was done on $5 \%(\mathrm{w} / \mathrm{v})$ polyacrylamide gels in TBE buffer according to Sambrook et al. (1989).

Purification of outer membranes. Outer membranes were prepared as previously described using the Sarkosyl differential solubilization 


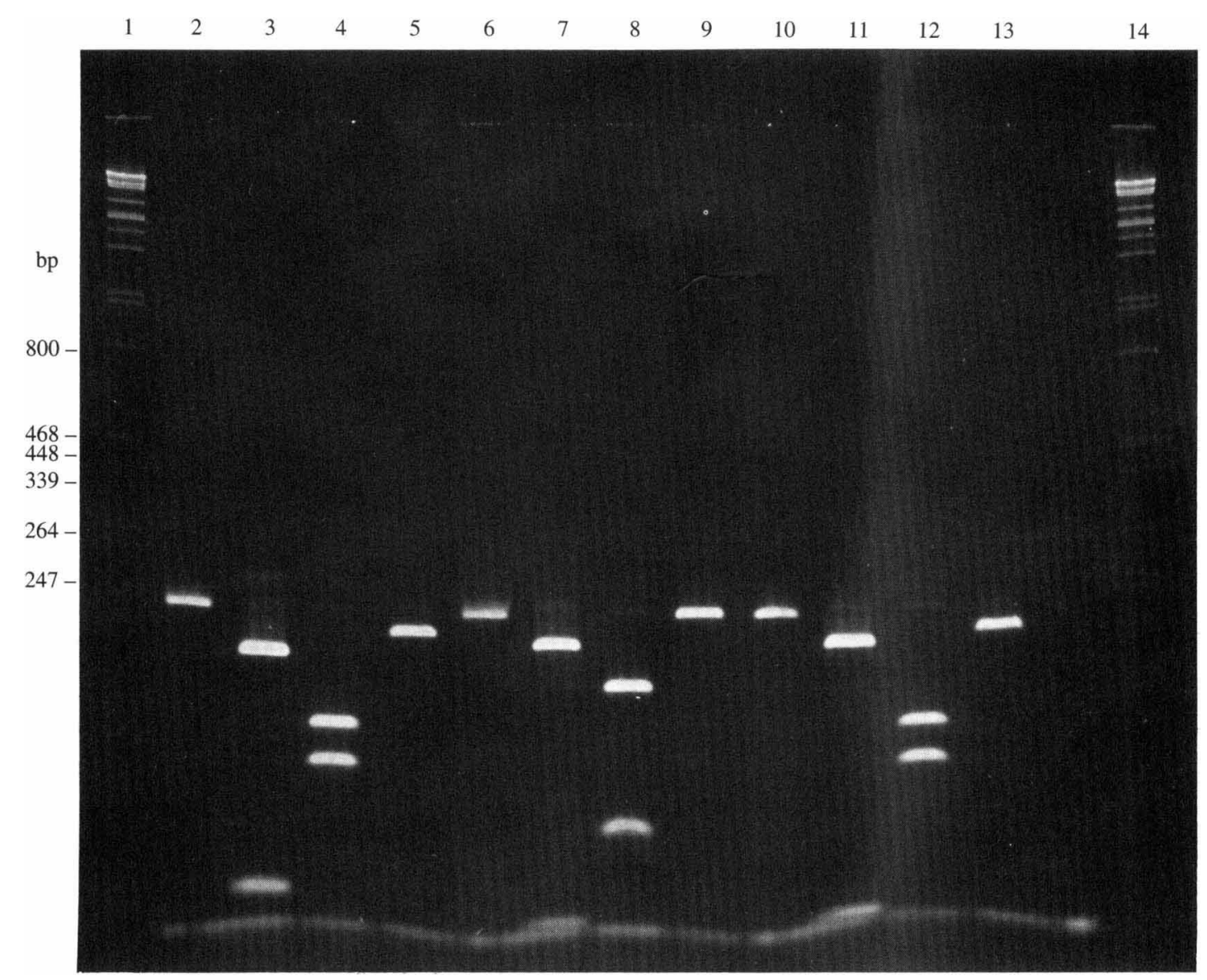

Fig. 1. PAGE of amplified oprI genes and their restriction digest products from: Pseudomonas aeruginosa PAO1 (lanes 2 to 5); $P$. reptilovora (lanes 6-9); and P. mendocina (lanes 10-13). PCR products were either undigested (lanes 2,6 and 10), or cut with restriction endonucleases HaeIIl (lanes 3, 7 and 11), PvuII (lanes 4,8 and 12) or SphI (lanes 5,9 and 13). Molecular mass markers, estimated from $\lambda$ cut with Pst (lanes 1 and 14), are indicated in base pairs.

method (Filip et al., 1973; Cornelis et al., 1989). The protein concentration was determined using a commercial kit (Bio-Rad) based on the Bradford colorimetric technique (Bradford, 1976).

Production of monoclonal antibodies. Adult female BALB/c mice were immunized in their footpads with outer-membrane preparations of $P$. aeruginosa PAO1 (Holmdahl et al., 1985). Nine days later the popliteal lymph nodes from 5 mice were collected, the lymphocytes extracted and fused with NSO myeloma cells. After $10 \mathrm{~d}$, the hybridoma were tested for the production of anti-OprI antibodies using an ELISA test with PAOl outer membranes as antigen. Positive clones were further tested in ELISA with outer membranes from $E$. coli cells expressing the recombinant Pseudomonas OprI and from cells containing the plasmid vector pKT240 only. Clones reacting specifically with the lipoprotein were further subcloned before injection into mice for the production of ascites fluid.

Immunological detection of the lipoprotein. The lipoprotein was detected by colony blots using the monoclonal antibodies (mAbs) $15 \mathrm{E} 11$ or $3 \mathrm{~A} 9$ (IgG2a). Each strain from different bacterial species was inoculated onto LB plates using sterile toothpicks and grown overnight at $28^{\circ} \mathrm{C}$. A nitrocellulose filter (Hybond $\mathrm{C}$, Amersham) was then laid on the colonies, lifted and the cells lysed by laying the filter, colony side up, on a paper pad saturated with lysis buffer ( $25 \mathrm{~mm}-\mathrm{Tris} / \mathrm{HCl} \mathrm{pH} 8$, 1 mM-EDTA, $1 \mathrm{mg}$ lysozyme $\mathrm{m}^{-1}$ ). After $30 \mathrm{~min}$, the filter was laid on another paper pad saturated with $25 \mathrm{~mm}$-Tris $/ \mathrm{HCl} \mathrm{pH} 8,1 \%(\mathrm{w} / \mathrm{v})$ sarkosyl. The membrane was then saturated with $3 \%$ bovine serum albumin (BSA) in phosphate-buffered saline (PBS) for $1 \mathrm{~h}$, incubated in a 1:500 dilution of the 15E11 or $3 \mathrm{~A} 9$ ascites fluid in PBS for $1 \mathrm{~h}$ at room temperature, washed three times in $0.1 \%$ PBS-Tween, incubated for $1 \mathrm{~h}$ with a 1:1000 dilution of horseradish peroxidase-conjugated protein A (Amersham), washed three times with PBS-Tween before detection with hydrogen peroxide and 4-chloro-1-naphthol (Bio-Rad). Western blots were performed according to Towbin et al. (1979) after separation of the outer membrane proteins on $15 \%(w / v)$ SDSpolyacrylamide gels. Dot blots on nitrocellulose filters were prepared by placing $100 \mathrm{ml}$ of 1:100 diluted outer membranes in PBS into each well of a Manifold apparatus (Schleicher and Schuell). Antibodies used were the same as in the colony blots.

\section{Results}

$P C R$ amplification of the oprI gene from $P$. aeruginosa

Thirty five $P$. aeruginosa strains tested for the in vitro amplification of the OprI lipoprotein gene consistently showed a unique amplification fragment of the expected size (249 bp) (Table 1, Table 2, Fig. 1, lane 1). Identical results were obtained for amplifications performed either on colony lysates or on purified DNA. 


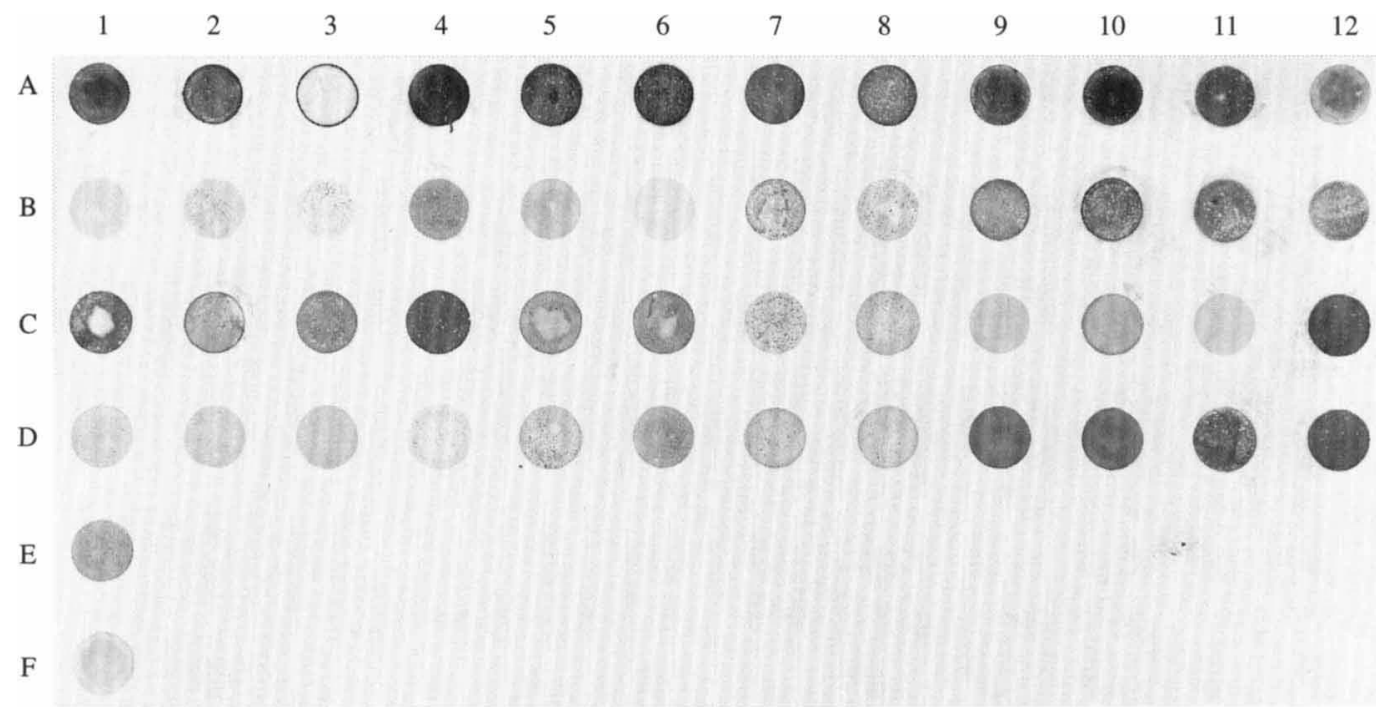

Fig. 2. Dot blot of outer membranes from different Pseudomonas and other species with the MAb 15E11. Al to C3 (from left to right and top to bottom): $P$. aeruginosa strains PAO1 (A1), MH1 (A2), MH2 (A3), MH3 (A4), MH4 (A5), MH6 (A6), MH7 (A7), MH8 (A8), MH9 (A9), MH10 (A10), PA3 (A11), PA6 (A12), PA10 (B1), PA11 (B2), PA12 (B3), PA1022 (B4), PA1601 (B5), PA2019 (B6), PS3711 (B7), PS3870 (B8), DW1 (B9), DW2 (B10), DW3 (B11), DW4 (B12), DW5 (C1), DW6 (C2) and 7NSK2 (C3). Wells C4 to E1: other rRNA group I $P$ seudomonas: $P$. alcaligentes LMG $1224^{\mathrm{T}}(\mathrm{C} 4), P$. agarici $\mathrm{LMG} 2112^{\mathrm{T}}(\mathrm{C} 5), P$. agarici $\mathrm{LMG} 2113(\mathrm{C} 6), P$. asplenii LMG $2137^{\mathrm{T}}(\mathrm{C} 7)$, $P$. aureofaciens LMG $1245^{\mathrm{T}}(\mathrm{C} 8)$, P. cichorii LMG $2162^{\mathrm{T}}$ (C9), $P$. chlororaphis $\mathrm{T} 9(\mathrm{C} 10)$, . fluorescens $\mathrm{ATCC} 17400$

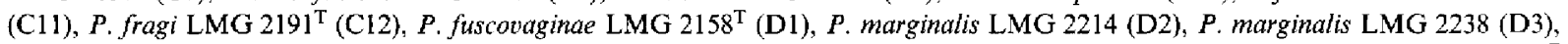
$P$. mendocina LMG $1223^{\mathrm{T}}$ (D4), $P$. oleovorans LMG $2229^{\mathrm{T}}$ (D5), $P$. pseudoalcaligenes LMG $1225^{\mathrm{T}}$ (D6), $P$. putida (A) LMG $2257^{\mathrm{T}}$ (D7), $P$. putida (B) LMG 1246 (D8), P. stutzeri LMG 2333 ${ }^{\mathrm{T}}$ (D9), $P$. syringae LMG 1247 (D10), $P$. taetrolens LMG $2336^{\mathrm{T}}$ (D11), $P$. tolaasii LMG $2340(\mathrm{D} 12)$ and $P$. tolaasii LMG $2342^{\mathrm{T}}(\mathrm{E} 1)$. Wells $\mathrm{E} 2$ to $\mathrm{E}$, other pseudomonads or related organisms: $(P$.) andropogonis LMG $2129^{\mathrm{T}}$ (E2), (P.) pickettii LMG 6871 (E3), (P.) solanacearum LMG 2296 (E4), ( $P$.) solanacearum LMG 2297 (E5), (P.) solanacearum LMG 2299 (E6), (P.) solanacearum LMG 2306 (E7), Xanthomonas maltophilia LMG 958 ${ }^{\mathrm{T}}$ (E8) and Azotobacter vinelandii LMG 3884 (E9). Well F1: positive control with membranes of $E$. coli (pLPI2), well F2: negative control with membranes of $E$. coli (pK T240). All other wells are empty.

$P C R$ amplification of the oprI gene in other members of the genus Pseudomonas and Gram-negative bacteria

From the results in Table 2, it is obvious that the oprI gene is conserved and restricted to the Pseudomonas species (21 tested) belonging to rRNA group I (Palleroni, 1984). All misnamed Pseudomonas species [21 strains tested, including Comamonas acidovorans, previously named (Pseudomonas) acidovorans and Sphingomonas paucimobilis, previously named (Pseudomonas) paucimobilis and Xanthomonas maltophilia, previously named (Pseudomonas) maltophilia] showed no amplification product. The conditions of amplification such as the annealing temperature were found to play a role in the specificity and signal intensity of the PCR reaction in $P$. aeruginosa and some other fluorescent pseudomonads. Exactly the same results were obtained at $60^{\circ} \mathrm{C}$ or at $64^{\circ} \mathrm{C}$ for the $P$. aeruginosa strains. However, for the other species (e.g. P. fuorescens, $P$. stutzeri and $P$. fragi) the amplification was weaker at $64{ }^{\circ} \mathrm{C}$ than at $60^{\circ} \mathrm{C}$ (results not shown). None of the other Gram-negative bacteria tested gave a positive reaction in the amplification reaction. Again, similar amplification results were obtained whether purified DNA or colony lysates were used as templates for PCR.

\section{Detection of the lipoprotein with monoclonal antibodies}

All of the strains tested by PCR were also screened for the presence of the lipoproteins by using $\mathrm{mAbs}$ raised against the lipoprotein of $P$. aeruginosa PAOI. $\mathrm{mAb}$ 15E11 was selected for further work since it reacted equally well in colony, dot and Western blots. The results obtained in colony blots and repeated in dot blots (Fig. 2) confirmed the observations of the previous PCR experiments (Table 2) in that only rRNA group I Pseudomonas species produced lipoprotein that reacted with $\mathrm{mAb}$ 15E11. A Western blot with outer membrane proteins from different PCR-positive rRNA group I Pseudomonas spp. showed that they all contained a lipoprotein of molecular mass about $12 \mathrm{kDa}$ (Fig. 3). The presence of bands of higher molecular mass may be explained by the fact that some of the lipoprotein is bound to peptidoglycan of variable length. Pseudomonas spp. that were not members of rRNA group I did not contain this lipoprotein (e.g. Fig. 3, lane 12) and did not 


$\begin{array}{llllllllllllll} & 1 & 2 & 3 & 4 & 5 & 6 & 7 & 8 & 9 & 10 & 11 & 12 \\ \mathrm{kDa} & & & & & & & & & & & & & \end{array}$

$45-$

$30-$

$21-$

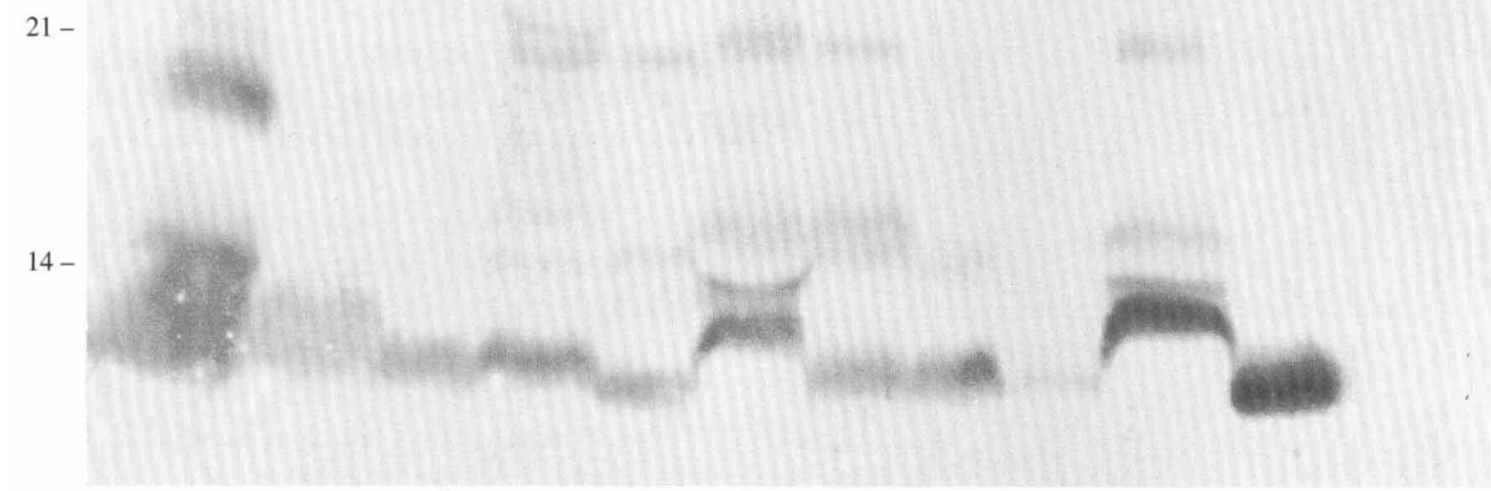

Fig. 3. Western blot of outer membrane proteins separated on $15 \%$ SDS-PAGE. Lanes: $1, P$. aeruginosa PAO1; $2, P$. aeruginosa MH9; 3. P. mendocina LMG $1223^{\mathrm{T}} ; 4$, P. stutzeri LMG $2333^{\mathrm{T}} ; 5$, P. putida (A) LMG $2257^{\mathrm{T}} ; 6$, P. putida (B) LMG 1246; 7 , P. fuorescens ATCC $17400 ; 8$, P. aureofaciens LMG $1245^{\mathrm{T}} ; 9, P$. cichorii LMG $2162^{\mathrm{T}} ; 10, P$. syringae LMG $1247 ; 11$, P. agarici LMG $2113 ; 12,(P$.) solanacearum LMG 2306. Molecular masses of protein markers are indicated on the left.

contain a protein band corresponding to the PAO1 lipoprotein in Coomassie Blue-stained SDSpolyacrylamide gels (results not shown).

\section{Restriction analysis of the oprI amplified fragment}

The 249 bp open reading frame of the lipoprotein gene contained unique HaeIII, PvuII and SphI sites at positions 49,112 and 228 , respectively, from the first codon. In order to determine whether these restriction sites were phylogenetically conserved, we digested all PCR fragments with the three enzymes. Fragments were visualized after electrophoresis on $5 \%$ polyacrylamide gels. The restriction sites were found to be conserved in all strains of $P$. aeruginosa, $P$. mendocina, $P$. oleovorans and $P$. pseudoalcaligenes tested (Fig. 1; Table 3). The amplified oprI-containing DNA fragments from other species showed a variety of restriction fragment length polymorphisms (RFLPs). In some fragments ( $P$. fragi, $P$. stutzeri, some strains of $P$. putida), all three sites were found to be absent while in others one or two sites were conserved. Some amplified fragments were restricted by a given enzyme but not at the same location as in $P$. aeruginosa, as seen for PvuII which cut the amplified fragment of P. reptilovora at a different location (Fig. 1, lane 8). Several strains of $P$. putida and $P$. fluorescens were tested giving different digestion patterns, confirming the well known heterogeneity of these two species for which different biotypes have been described (Palleroni, 1984).

\section{Discussion}

The sequence of the oprI gene from $P$. aeruginosa indicated that it differed from the other lipoprotein genes already cloned and sequenced from Enterobacteriaceae (Cornelis et at., 1989), and suggested that it would be a suitable target for the detection of $P$. aeruginosa either by PCR or by immunological techniques involving mAbs. Recently, Saint-Onge et al. (1992) showed that amplification of the oprI open reading frame by PCR was possible in only a number of Pseudomonas species 
Table 3. Restriction patterns of the oprI gene in $r R N A$ group I Pseudomonas spp.

\begin{tabular}{|c|c|c|c|c|}
\hline \multirow[t]{2}{*}{ Pseudomonas spp. } & \multirow[t]{2}{*}{$\begin{array}{l}\text { Number } \\
\text { of strains } \\
\text { tested }\end{array}$} & \multicolumn{3}{|c|}{ Restriction sites } \\
\hline & & HaelII & PvuII & $S p h \mathbf{I}$ \\
\hline P. aeruginosa & 17 & + & + & + \\
\hline P. mendocina & 1 & + & + & + \\
\hline$P$. oleovorans & 1 & + & + & + \\
\hline$P$. psendoalcaligenes & 1 & + & + & + \\
\hline P. alcaligenes & 1 & + & + & - \\
\hline P. fuscovaginae & 1 & + & + & - \\
\hline$P$, reptilovora & 1 & + & $(+)$ & - \\
\hline$P$. aureofaciens & 1 & + & - & - \\
\hline P. chlororaphis & 1 & + & - & - \\
\hline$P$. fiuorescens & 1 & + & - & - \\
\hline P. marginalis & 1 & + & - & - \\
\hline P. fragi & 1 & - & - & - \\
\hline P. putida A & 1 & - & - & - \\
\hline P. stutzeri & 1 & - & - & - \\
\hline P. asplenit & 1 & - & + & + \\
\hline P. fuorescens & 5 & - & + & + \\
\hline P. corrugata & 1 & - & - & + \\
\hline P. syringae & 1 & - & - & + \\
\hline P. fuorescens & 3 & - & + & - \\
\hline P. putida B & 1 & - & + & - \\
\hline P. agarici & 1 & + & - & + \\
\hline P. tolaasii & 1 & + & - & + \\
\hline
\end{tabular}

(+), The Pvull site was at a different position.

belonging to rRNA group I (Palleroni, 1984). In general, our data support and extend the observations of SaintOnge et al. (1992); we included representatives of thirteen other Pseudomonas species from this rRNA group as well as a wide variety of so-called $P_{\text {seudomonas }}$ species from other rRNA groups. However, in contrast to their study, none of the $35 P$. aeruginosa isolates tested here was negative in the PCR reaction. Chryseomonas luteola is a free-living nitrogen-fixing species recently classified in

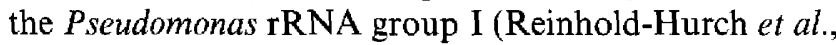
1993). However, PCR and Western blot results presented here and by Saint-Onge et al. (1992) suggested that OprI and its gene in this organism were atypical for the group, even though Southern blot results of Saint-Onge et al. (1992) indicated that $C$. luteola contained DNA sequences that hybridized with oprI from $P$. aeruginosa. Thus, although rRNA group I Pseudomonas species showed positive amplification of the oprI gene, some exceptions may be expected as organisms from genera such as Chryseomonas, Azotobacter and Azomonas are classified close to rRNA group I pseudomonads (De Vos \& De Ley, 1983).

It should be noted that sensitivity of the PCR technique described here means that great care has to be taken to avoid contamination which may produce false positive results, especially in general and clinical microbiological laboratories. In this study positive and negative controls were included in each batch of PCR reactions, and results from PCR assays using both colony lysates and extracted DNAs as templates were confirmed with Western blots using mAb 15E11. Both techniques also showed negative reactions for the misnamed pseudomonads belonging to the 'Pseudomonas' rRNA groups II, III and IV (Palleroni, 1984) and other Gram-negative species (Table 2). These findings are consistent with the known large phylogenetic distances between these rRNA groups and the authentic pseudomonads (De Vos \& De Ley, 1983). Similar results were obtained by Siehnel et al. (1990) who investigated the relatedness of $\operatorname{opr} P$ genes (the phosphate-specific porin in $P$. aeruginosa), and reported cross-hybridization only between members of rRNA group I and not with species belonging to the other groups.

Since amplification of the oprI gene by itself would not discriminate between rRNA group I Pseudomonas species, RFLP analysis of the PCR products was carried out using restriction endonucleases HaeIII, PvuII and $S p h I$. Our results showed eight different restriction profiles within the rRNA group I pseudomonads (Table 3). In all $17 \quad P$. aeruginosa strains tested, the three different restriction sites were present at the same sequence-predicted location. This is in excellent agreement with previous sequence data from three strains of $P$. aeruginosa, which showed very little variation in the oprI open reading frames (Cornelis et al., 1989; Duchêne et al., 1989; Saint-Onge et al., 1992). Ullstrom et al. (1991) also found conservation of restriction sites in the $o p r F$ gene in the 17 serotypes of $P$. aeruginosa, with the exception of serotype 12. The same restriction pattern (Table 3) was found for $P$. pseudoalcaligenes, $P$. oleovorans and $P$. mendocina. DNA:DNA hybridization data (Palleroni et al., 1972) showed that $P$. aeruginosa was most closely related to $P$. pseudoalcaligenes, which is in good agreement with our results. However, the same study showed only slight homology between $P$. mendocina and $P$. aeruginosa, and no DNA relatedness data were reported for $P$. oleovorans.

Although there was considerable restriction fragment length polymorphism in the amplified DNA fragments containing oprI at the species and sub-species level (Table 3), mAb 15E11 reacted with the OprI lipoprotein from all PCR-positive strains. This suggested that the epitope is conserved and that the nucleotide sequence variation may be confined to the third base of the codons. Finke et al. (1991) have already identified two epitopes in the $P$. aeruginosa lipoprotein, one at the Nterminal and one at the C-terminal.

In terms of the development of diagnostic methods and looking for markers of interest to the taxonomist we can conclude that the data on oprI presented here allowed differentiation of $P$. aeruginosa from all but 
three ( $P$. mendocina, $P$. pseudoalcaligenes and $P$. oleovorans) rRNA group I Pseudomonas species. However, a more detailed analysis would be required to determine if the OprI lipoprotein is suitable for the differentiation between the fluorescent pseudomonads at species or subspecies levels.

Our thanks to Professor R. Hamers for stimulating discussions. P.D.V. is indebted to the National Fund for Scientific Research (Belgium) for a position as Research Associate. We wish also to thank W. Verheulpen and J. Doumen for their assistance in computer work.

\section{References}

Bodey, G. P., Bolivar, R., Fainstein, V. \& Jadeja, L. (1983). Infections caused by Pseudomonas aeruginosa. Reviews of Infectious Diseases 5, 279-313.

Bodey, G. P., Jadeja, L. \& Elting, L. (1985). Pseudomonas bacteremia: retrospective analysis of 410 episodes. Archives of Internal Medicine 145, 1621-1629.

BotzenharT, K. \& Rüden, H. (1987). Hospital infections caused by Pseudomonas aeruginosa. Antibiotics and Chemotherapy 39, 1-15.

BRADFORD, M. M. (1976). A rapid and sensitive method for the quantitation of microgram quantities of protein utilizing the principle of protein-dye binding. Analytical Biochemistry 76, 248-254.

Cornelis, P., Bouta, A., Guyonvarch, A., Kammerer, B., Hannaert, V. \& HUBERT, J. C. (1989). Cloning and analysis of the gene for the major outer membrane lipoprotein from Pseudomonas aeruginosa. Molecular Microbiology 3, 421-428.

Davison, J. (1988). Plant beneficial bacteria. Bio/Technology 6, 282-286.

DE Vos, P. \& DE LeY, J. (1983). Intra- and intergeneric similarities of Pseudomonas and Xanthomonas ribosomal ribonucleic acid cistrons. International Journal of Systematic Bacteriology 33, 487-509.

De Vos, P., Goor, M., Gillis, M. \& De LeY, J. (1985). Ribosomal ribonucleic acid cistron similarities of phytopathogenic Pseudomonas species. International Journal of Systematic Bacteriology 35, 169-184.

De Vos, P., Van Landschoot, A., Segers, P., Tytgat, R., Gillis, M., Bauwens, M., Rossau, R., Goor, M., Pot, B., Kersters, K. Lizzaraga, P. \& De Ley, J. (1989). Genotypic relationships and taxonomic localization of unclassified Pseudomonas and Pseudomonas-like strains by deoxyribonucleic acid:ribosomal ribonucleic acid hybridizations. International Journal of Systematic Bacteriology $39,35-49$.

Duchêne, M., Barron, C., Schweizer, A., von Specht, B. U. \& DOMDEY, H. (1989). Pseudomonas aeruginosa outer membrane lipoprotein I gene: molecular cloning, sequence, and expression in Escherichia coli. Journal of Bacteriology 171, 4130-4137.

Filip, C., Fletcher, G., WulfF, J. L. \& Earhart, C. F. (1973). Solubilisation of the cytoplasmic membrane of Escherichia coli by the ionic detergent sodium-lauryl-sarcosinate. Joumal of Bacteriology 115, 717-722.

Finke, M., Muth, G., Reichelm, T., Thoma, M., Duchêne, M., Hungerer, K. D., DOMDey, H. \& von SPecht, B. U. (1991). Protection of immunosuppressed mice against infection with $P$ seudomonas aeruginosa by recombinant $P$. aeruginosa lipoprotein I and lipoprotein I-specific monoclonal antibodies. Infection and Immunity 59, 1251-1254.

Govan, J. R. W. (1986). Pseudomonas aeruginosa and cystic fibrosis: unusual bacterial adaptation and pathogenesis. Microbiological Science 3, 302-308.

Hoiby, N., Döring, G. \& Schiotz, P. O. (1987). Pathogenic mechanisms of chronic Pseudomonas aeruginosa infections in cystic fibrosis patients. Antibiotics and Chemotherapy 39, 60-76.

HOLMDAHL, R., MORAN, T. \& ANDERSSON, M. (1985). A rapid and efficient immunization protocol for production of monoclonal antibodies reactive with autoantigens. Journal of Immunological Methods 83, 379-384.

Mondino, B. J., Weissman, B. A., Farb, M. D. \& Pettit, T. H. (1986). Corneal ulcers associated with daily wear and extended wear contact lenses. American Journal of Ophthalmology 102, 58-65.

Palleroni, N. J. (1984). Genus I. Pseudomonas Migula 1894. In Bergey's Manual of Systematic Bacteriology vol. 1, pp. 141-199. Edited by N. R. Krieg \& J. G. Holt. Baltimore: Williams \& Wilkins.

Palleroni, N. J., Ballard, R. W., Ralston, E. \& Doudoroff, M. (1972). Deoxyribonucleic acid homologies among some Pseudomonas species. Journal of Bacteriology 110, 1-11.

Reinhold-Hurek, B., HuReK, T., Gillis, M., HOSTE, B., VANCANNEYT, M., Kersters, K. \& De LeY, J. (1993). Azoarcus gen. nov., nitrogen-fixing Proteobacteria associated with roots of Kallar Grass (Leptochloa fusca (L.) Kunth), and description of two species, Azoarcus indigens sp. nov. and Azoarcus communis sp. nov International Journal of Systematic Bacteriology 43, 574-584.

Saint-Onge, A., Romeyer, F., Lebel, P., Masson, L. \& Brousseau, R. (1992). Specificity of the Pseudomonas PAOl lipoprotein 1 gene as a DNA probe and PCR target region within the Pseudomonadaceae. Journal of Genteral Microbiology 138, 733-741.

Sambrook, J., Fritsch, E. F. \& Maniatis, T. (1989). Molecular Cloning, a Laboratory Manual. Cold Spring Harbor, NY: Cold Spring Harbor Laboratory.

Siehnel, R., Martin, N. L. \& Hancock, R. E. W. (1990). Sequence and relatedness in other bacteria of the Pseudomonas aeruginosa OprP gene coding for the phosphate-specific porin P. Molecular Microbiology 4, 831-838.

Towbin, H., Staehelin, T. \& Gordon, J. (1979). Electrophoretic transfer of proteins from polyacrylamide gels to nitrocellulose sheets: procedures and some applications. Proceedings of the National Academy of Sciences of the United States of America 76, $4350-4354$.

Ullstrom, C. A., Siehnel, R., Woodruff, W., Steinbach, S. \& HANCOCK, R.E. (1991). Conservation of the gene for outer membrane protein OprF in the family Pseudomonadaceae: sequence of the Pseudomonas syringae $\mathrm{OprF}$ gene. Journal of Bacteriology 173, 768-775.

WELLER, D. M. (1988). Biological control of soilborne plant pathogens in the rhizosphere with bacteria. Annual Review of Phytopathology 26, 379-407. 